\title{
COMBATING CORRUPTION: SOME REFLECTIONS ON THE USE OF THE OFFENCE AND THE TORT OF MISCONDUCT/MISFEASANCE IN A PUBLIC OFFICE
}

\author{
John Hatchard*
}

\section{INTRODUCTION}

After several years of controversy and uncertainty, on 8 April 2010 the Bribery Act 2010 received the Royal Assent. ${ }^{1}$ The Act swept away the unsatisfactory, fragmented and complex corruption offences at common law and under the Prevention of Corruption Acts $1889-1916^{2}$ and in their place created two general corruption offences (the offence of bribing another person and the offence of being bribed, each of which may be committed in the public or private sector), a discrete offence of the bribery of a foreign public official and an entirely new offence of failure by a commercial organisation to prevent a bribe being paid. ${ }^{3}$

Yet whilst an important milestone, the Bribery Act did not repeal the common law offence of misconduct in a public office ${ }^{4}$ nor, of course, did it impact on the tort of misfeasance in public office. For many years, these were both somewhat neglected avenues for dealing with corrupt public officials but recently they have found a new lease of life. ${ }^{5}$ The offence has become increasingly popular with prosecutors not only in England and Wales ${ }^{6}$ but in

\footnotetext{
* John Hatchard, LLB, LLM, Barrister, Professor of Law, University of Buckingham Law School. This is an expanded and updated article that is based on a chapter written for C Nicholls, T Daniel, A Bacarese and J Hatchard Corruption and Misuse of Public Office (Oxford: Oxford University Press, $2^{\text {nd }}$ edn, 2011) (hereafter 'Nicholls').

1 The Act came into force on 1 July 2011.

2 It also repealed sections 108-110 Anti-terrorism, Crime and Security Act 2001 which extended the jurisdiction of UK courts to include the bribery of foreign public officials and corruption abroad by UK nationals and companies incorporated in the UK.

${ }^{3}$ See generally Nicholls, chapter 4 .

${ }^{4}$ The offence is sometimes referred to as misfeasance in a public office.

${ }^{5}$ Indeed in Davis v Bromley Corporation [1908] 1 KB 170, the Court of Appeal held the tort of misfeasance did not exist.

6 Statistics on the number of persons proceeded against in magistrates' courts in England and Wales between 1998 and 2007 can be found in a paper by L Maer "Misconduct in Public Office" (2009) House of Commons Library p 11.
} 


\section{COMBATING CORRUPTION}

other jurisdictions such as $\mathrm{Canada}^{7}$ and Hong Kong. ${ }^{8}$ Its importance as a weapon through which to combat corrupt practices is also highlighted by the inclusion of an "abuse of functions" offence in the United Nations Convention Against Corruption (UNCAC). ${ }^{9}$ Furthermore, the tort of misfeasance in a public office "bears some resemblance to the crime of misconduct in a public office" $" 10$ and is now well established and is increasingly used in Commonwealth countries. ${ }^{11}$

Several recent cases have explored and extended the scope of both the crime and the tort. This article explores these developments and, in particular, considers the contribution that both the crime and the tort can have in the fight against corruption and misuse of public office. In the first section, the offence of misconduct in a public office is considered whilst the second section explores the tort of misfeasance in a public office. The final section provides a short conclusion.

\section{SECTION 1: THE CRIMINAL OFFENCE OF MISCONDUCT IN PUBLIC OFFICE}

The offence of misconduct in public office is an ancient one. Pollock and Maitland trace it back to the $13^{\text {th }}$ century ${ }^{12}$ although the starting point for the development of the present offence essentially goes back over two hundred years to the judgment of Lord Mansfield CJ in $R v$ Bembridge $^{13}$ who identified two principles. Firstly that:

“...a man accepting an office of trust, concerning the public, especially if attended with profit, is answerable criminally to the King for

${ }^{7}$ See Article 122 of the Criminal Code of Canada (the offence of Breach of Trust by a Public Officer). See further the discussion in $R v$ Boulanger [2006] 2 SCR 49 (Supreme Court of Canada).

${ }^{8}$ Hong Kong has retained the common law offence: see Shum Kwok Shur v HKSAR [2002] 5 HKCFAR 381 (Hong Kong Court of Final Appeal).

${ }^{9}$ See Article 19 which is noted below.

${ }^{10}$ See Lord Steyn in Three Rivers District Council v Bank of England (No 3) [2003] 2 AC 1 para 191.

${ }^{11}$ See the views of Lord Diplock in Dunlop $v$ Woolahra Municipal Council [1982] AC 158 at 172 and Brennan J in Northern Territory of Australia v Mengel (1995) 69 ALJR 527.

${ }^{12}$ F Pollock and F Maitland The History of English Law (Cambridge: Cambridge University Press, 2nd edn, 1898, Vol 2) pp 520-521, who trace the offence back to the 13th century: see $R v W$ [2010] EWCA Crim 372 para 1.

13 (1783) 3 Doug 327; 99 ER 679. For earlier cases see Mackalley's Case (1611) 9 Co Rep 656; Crouther's Case (1600) Cro Eliz 654; 78 ER 893 and Anonymous (1704) 87 ER 853. 
misbehaviour in his office; this is true by whomever and in whatever way the officer is appointed."

Secondly, "where there is a breach of trust, fraud or imposition, in a matter concerning the public, though as between individuals it would only be actionable, yet as between the King and the subject it is indictable". ${ }^{14}$

Thus the offence is essentially a support for integrity and good governance on the basis that those who are entrusted with state power must act for the public good. Whilst many of the reported cases involve police officers, the offence applies generally to officials in the public service, local government ${ }^{15}$ and, arguably those in the private sector providing public functions. ${ }^{16}$ Its growing importance is due to several reasons. Firstly, it can be used to prosecute corrupt practices by public officials, for example where a public official awards a lucrative government contract to a company of which $\mathrm{s} / \mathrm{he}$ is a secret beneficiary or arranges for the sale of government land to a company owned or controlled by his/her family at a price far below the market value. ${ }^{17}$ A charge of conspiracy to cause misconduct in public office is also available for use against those seeking to corrupt public officials. ${ }^{18}$

Secondly a single charge of misconduct in a public office may reflect a course of conduct or address a situation where no financial reward is involved. For example, in Sin Kam Wah $v H K S A R^{19}$ the accused, a senior police officer, was in command of a department responsible for investigating vice offences. He was convicted on three charges of misconduct in that on several occasions he had been provided with prostitutes by the owner of several night clubs in return for protection from police investigation. In $R v$ McDade a former female prison officer pleaded guilty to the misconduct offence following her "inappropriate relationship with an inmate under her care", which included a sexual relationship with him and the smuggling of items into the prison on his behalf. ${ }^{20}$

Thirdly it can apply to a somewhat disparate range of acts and omissions where these go beyond the need for disciplinary action. Thus in the well-

\footnotetext{
14 At page 681 .

${ }^{15}$ Such as in $R v$ Bowden above $\mathrm{n} 34$.

16 The scope of the term "public servant" is considered below.

${ }^{17}$ See, for example Marin \& Coye v Attorney General of Belize [2011] CCJ 9 (AJ) which is discussed in detail below.

18 For example, in July 2012 two journalists were arrested and charged with conspiracy to corrupt and conspiracy to cause misconduct in a public office. This was part of Operation Elveden, a police investigation into alleged corrupt payments by journalists to police officers to obtain information.

${ }_{19}$ [2005] 2 HKLRD 375.

20 Unreported, CPS press release 13 November 2009. She was sentenced to 30 months' imprisonment.
} 


\section{COMBATING CORRUPTION}

known case of $R v$ Dytham $^{21}$ a police officer was convicted of the misconduct offence when, whilst on duty and in uniform, he witnessed a fatal assault on a man by a number of assailants. The officer took no steps to intervene and, when it was over, merely drove away. Similarly, in $R v$ Burrows $^{22}$ the defendant who was a probationary police officer had been called to assist at a public order incident at which a fellow officer had assaulted a man before arresting him. In order to protect his fellow officer, the defendant wrote false notes of the incident and falsely claimed that he had arrested one of the men involved. He admitted the offence of misconduct in a public office. Again, in $R v W^{23}$ a police officer was charged with the misconduct offence when he used a police credit card for his own personal expenditure as well as official expenses contrary to Force Instructions, albeit that the practice was widely followed by very large numbers of his colleagues. ${ }^{24}$

The failure to protect vulnerable persons is another area where the offence is applicable. For example in $R v$ Harrington, a police officer pleaded guilty to misconduct in a public office on the basis of committing sexual acts upon an alleged victim of a sexual assault to whom he had been appointed as chaperone. The case against him was put on the basis that he had a duty to ensure that the woman was treated with kindness and sympathy in order to obtain the best possible evidence from her to aid the investigation of the sexual assault in respect of which she was the victim. ${ }^{25}$

Fourthly, given that the offence carries a maximum sentence of life imprisonment, it can be used in a variety of circumstances where other charges may not necessarily be applicable or appropriate or where the court's sentencing powers are otherwise inadequate. An important contemporary example is the unauthorised leaking of official information, an area in which the offence is proving particularly useful to prosecutors. ${ }^{26}$ Thus in $R v$ LundLack, ${ }^{27}$ a civilian working for a police counter-terrorism unit was convicted of misconduct in public office when he leaked information to a journalist about a

${ }^{21}$ [1979] QB 722.

${ }^{22}$ Unreported, Middlesex Guildhall Crown Court, 2005.

${ }^{23}$ [2010] EWCA Crim 372.

${ }^{24}$ His appeal against conviction was upheld due to the misdirection of the trial judge regarding the mens rea for the offence.

${ }^{25}$ Unreported, Central Criminal Court, 2003. The accused was sentenced to six months' imprisonment.

${ }^{26}$ Indeed paragraph 31 of the interpretative notes to UNCAC indicates that the Article 19 "abuse of functions" offence may encompass a range of conduct such as improper disclosure by a public official of classified or privileged information: (A/58/422/Add.1, para. 31).

${ }^{27}$ Unreported, Kingston Crown Court, 2007. He was sentenced to eight months' imprisonment. 
planned al-Qaeda attack. In $R v$ Turner $^{28}$ a police officer was convicted of the offence when over a period of about 18 months and on a large number of occasions, he accessed records held on police computers and passed this information on to criminals. In dismissing his appeal, Lord Judge emphasized that "At the risk of repetition, police officers who access records and computers kept by the police for police purposes must be deterred, and deterrent sentences will be passed". ${ }^{29}$

\section{THE ELEMENTS OF THE OFFENCE}

The long line of cases that have explored the elements of the offence were considered by Pill LJ in the seminal case of Attorney-General's Reference (No 3 of 2003) (hereafter A-G Ref 2003). ${ }^{30}$ From these he concluded that the elements of the offence are:

i) A public officer acting as such;

ii) Wilfully neglects to perform his duty and/or wilfully misconducts himself;

iii) To such a degree as to amount to abuse of the public's trust in the office holder;

iv) Without reasonable excuse or justification. ${ }^{31}$

It is useful to consider each element separately.

\section{i) A Public Office Holder}

Over the years, the scope of a "public office holder" has been extended. As noted earlier, in $R v$ Bembridge Lord Mansfield CJ referred to a person "accepting an office of trust, concerning the public" whilst in $R v$ Whitaker $^{32}$ it was stated that a public officer "is an officer who discharges any duty in the discharge of which the public are interested, more clearly so if he is paid out of a fund provided by the public". ${ }^{33}$ In $R v$ Bowden ${ }^{34}$ the Court of Appeal concluded that the offence applies generally to every person who is appointed to discharge a public duty and is paid compensation in whatever form, whether from the Crown or otherwise. The key issue therefore is whether the

\footnotetext{
${ }^{28}$ [2009] EWCA Crim 2219.

29 At para 35. Turner was sentenced to twelve months' imprisonment.

${ }^{30}$ [2004] EWCA Crim 868.

31 At para 61 .

32 [1914] 3 KB 1283.

33 At page 1296.

${ }^{34}$ [1996] 1 WLR 98; [1996] Cr App R 104.
} 


\section{COMBATING CORRUPTION}

public has an interest in the proper discharge of the duty placed upon the individual. ${ }^{35}$ The issue of remuneration is discussed below.

Who then is classified as a "public official" for the purposes of the offence? Willes $\mathrm{J}$ in $R \quad v$ Lancaster and Worrell" $l^{36}$ concluded that "the application and the principle is not confined to public servants in the narrow sense, under the direct orders of the Crown". Thus seemingly it is not necessary that the individual in question is "appointed" to the post. This was certainly the view of the majority in the Australian case of $R v$ Boston $^{37}$ who held that the post of a Member of Parliament was a public office. ${ }^{38}$ The term also seemingly covers the significant number of public sector workers who are paid through private companies. As Pill LJ noted in A-G Ref 2003, "public functions are now frequently carried out by employees in private employment, for example those concerned with security at courts and the transport of defendants". ${ }^{39}$ However the court declined to address the attractive submission of counsel that it is unfair and illogical if those holding a public office, such as police officers, are to be liable to a sanction not applicable to those in private employment who do similar work.

A "flexible approach" to the issue is also illustrated in the recent case of $R$ $v$ Belton ${ }^{40}$ where Goss LJ in the Court of Appeal regarded a volunteer prison visitor with the Independent Monitoring Board as a public servant on the basis that:

"It seems most improbable that a person would be given such an entitlement [i.e. to visit any place in the prison and to interview any prisoner] if not the holder of a public office, or otherwise, under some suitable contractual arrangement with the prison [my emphasis]."

If this statement is correct, then this represents a potentially significant widening of the scope of the offence and makes identifying its limits even more challenging. In such circumstances, it is perhaps preferable to focus on

35 It was also noted that a "public office" was correctly defined in Henly $v$ Lyme Corporation (1828) 5 Bing New Cases 91 where the case involved a mayor and burgesses of a borough.

${ }^{36}$ (1890) 16 Cox CC 739.

37 (1923) 33 CLR 386.

${ }^{38}$ In $R v$ Currie Unreported, Central Criminal Court, 1992, Buckley, J as trial judge, ruled that an MP was the holder of a public office for the purposes of the common law offence of bribery. In the Galley and Green case, discussed below, the issue was not raised in circumstances where a serving member of Parliament was investigated on suspicion of being an accessory to the misconduct offence.

39 Para 62.

${ }^{40}$ [2010] EWCA Crim 2857. 
the nature and extent of the duty undertaken and thus adopt a functional rather than a titular approach to the issue.

The issue of whether there is a requirement that the public servant was in receipt of any remuneration in order to establish the offence was also considered in $R v$ Belton. The decision itself hinged upon the correctness of the pre-trial ruling that "there is no requirement in law that someone must be remunerated in order to be a public officer". In the Court of Appeal, Gross LJ referred to the words of Lord Mansfield CJ in $R v$ Bembridge noted earlier and also the view of AT Lawrence $\mathrm{J}$ in $R v$ Whitaker" $^{41}$ that a "public office holder is an officer who discharges any duty in the discharge of which the public are interested, more clearly so if he is paid out of a fund provided by the public" (my emphasis). He also noted that in $R v$ Borron $^{42}$ an unpaid magistrate was also charged with the misconduct offence ${ }^{43}$ and that Pill LJ in Att-Gen Ref 2003 when setting out the elements of the modern offence made no reference to the point. Accordingly, Gross LJ took the view that "remuneration is indicative but not determinative" of the issue and is thus not an indispensable requirement for the offence of misconduct in public office. ${ }^{44}$

The effect of the judgment is to confirm that the offence also potentially applies to a range of unpaid individuals operating within the public sector "including magistrates, special constables, perhaps local councillors and high sheriffs". In the case of volunteers "each case must turn on its own facts" and this inevitably raises uncertainty about those affected and in what circumstances. As was recognised in Belton, liability in each case will seemingly depend upon the scope of the volunteer's duties and powers. ${ }^{46}$

\section{ii) Wilfully Neglects to Perform a Duty and/or Wilful Misconduct}

It is useful to explore firstly the scope of the offence as this issue directly impacts on the mens rea requirement. The misconduct offence has always applied to corrupt practices. Thus in $R v$ Bembridge, Lord Mansfield CJ emphasised the need to prove that the defendant acted "corruptly and fraudulently" whilst in $R v$ Williams he referred to the need for a "corrupt motive". None of the later cases have seemingly explored what constitutes

\footnotetext{
${ }^{41}$ [1914] 3 KB 1283.

42 (1820) 3 B \& Ald 432.

${ }^{43}$ Although the charge was dismissed on other grounds.

${ }^{44}$ See para 30.

${ }^{45}$ Per Goss LJ at para 29.

${ }^{46}$ Gross LJ emphasised that "For the avoidance of any doubt it does not follow ... that every volunteer on every 'quango' will hold public office" at para 17.

${ }^{47}$ See $R v$ Bembridge (1783) 3 Doug 327; 99 ER 679, and $R v$ Llewellyn-Jones [1968] 1 QB 429.
} 


\section{COMBATING CORRUPTION}

"corruption" in this context whilst relevant international instruments are also largely silent on the point. For example, "corruption" is not defined in the United Nations Convention Against Corruption which merely requires State Parties to adopt (or in some cases to consider adopting) a series of, what might be termed "corruption and related offences" that include bribery, trading in influence and, in Article 19 an offence of "abuse of functions" in the following terms:

"Each State Party shall consider adopting such legislative and other measures as may be necessary to establish as a criminal offence, when committed intentionally, the abuse of functions or position, that is, the performance of or failure to perform an act, in violation of laws, by a public official in the discharge of his or her functions, for the purpose of obtaining an undue advantage for himself or herself or for another person or entity".

The case of Magill $v$ Weeks ${ }^{48}$ indicates that "corruption" goes beyond obtaining a financial advantage. In the House of Lords, Lord Bingham of Cornhill described the actions of certain local councillors in designating council houses for sale in the hope of electoral advantage as a "deliberate, blatant and dishonest misuse of public power. It was a misuse of power by both of them not for the purpose of financial gain but for that of electoral advantage. In that sense it was corrupt" ${ }^{49}$ As Lord Scott of Foscote also emphasised:

"This is a case about political corruption. The corruption was not money corruption. No one took a bribe. No one sought or received money for political favours. But there are other forms of corruption, often less easily detectable and therefore more insidious. Gerrymandering, the manipulation of constituency boundaries for party political advantage, is a clear form of political corruption. So, too, would be any misuse of municipal powers, intended for use in the general public interest but used instead for party political advantage. Who can doubt that the selective use of municipal powers in order to obtain party political advantage represents political corruption? Political corruption, if unchecked, engenders cynicism about elections, about politicians and their motives and damages the reputation of democratic government". ${ }^{50}$

48 [2001] UKHL 67.

49 At para 48.

${ }^{50}$ At para 132. 
Of course the offence goes beyond "corrupt" conduct and is said also to cover those "whose activities include extortion, fraud and oppression". ${ }^{51}$ In $R$ $v$ Dytham $^{52}$ it was said that the offence "is more vividly exhibited where dishonesty is revealed as part of the dereliction of duty". ${ }^{53}$ In the important recent case of $R v W^{54}$ the Court of Appeal recognised that the nature of the conduct falling within the ambit of the offence is very wide and noted that the Salmon Report had observed that the offence "embraces a wide variety of misconduct including acts done with a dishonest, oppressive or corrupt motive". ${ }^{55}$ Further that "its principal applications are said to include: (a) frauds and deceits (fraud in office); (b) wilful neglect of duty (nonfeasance); (c) "malicious" exercises of official authority (misfeasance); (d) wilful excesses of official authority (malfeasance); and (e) the intentional infliction of bodily harm, imprisonment, or other injury upon a person (oppression)". ${ }^{56}$ What is clear is that there is a critical distinction between breaches of public duty emanating from a corrupt, fraudulent etc motive, which fall within the criminal offence, and mistakes or errors by public officials, however serious, which do not. ${ }^{57}$

The majority of reported cases focus on allegations of misconduct by public officials. However, identifying the scope of the offence, and therefore the mens rea requirement, is complicated by the fact that there developed a separate line of cases dealing with public officials who neglected their official duties. Thus in the early case of $R v$ Wyat ${ }^{58}$ it was said that where "... an officer neglects a duty incumbent on him, either by common law or statute, he is for his default indictable". ${ }^{59}$ In fact Stephen in his Digest of the Criminal Law identified two separate offences, firstly "frauds and breaches of trust by officers" and secondly "neglect of official duty". ${ }^{60}$ Thus in Dytham (noted earlier), whilst there was no corruption or dishonesty alleged, Lord Widgery CJ concluded the accused could be convicted of a wilful neglect of duty, with the element of culpability being "of such a degree that the misconduct impugned is calculated to injure the public interest so as to call for

${ }^{51} R v$ Llewellyn-Jones [1968] 1 QB 429. Here a county court registrar exercised his judicial responsibility with the intention of gaining an improper personal advantage.

${ }_{52}^{2}$ [1979] QB 722.

${ }^{53}$ Per Lord Widgery CJ at 726.

${ }_{55}^{5}$ [2010] EWCA Crim 372.

55 Report of the Royal Commission on Standards in Public Life 1974-76 (the Salmon Commission) Cmnd 5624.

${ }^{56}$ Referring to an article by P D Finn "Official Misconduct" [1978] 2 Crim LJ 308.

${ }^{57}$ A point made by Abbott CJ in $R v$ Borron (1820) 3 B \& Ald 432.

${ }^{58}$ (1705) 91 ER 331.

${ }^{59}$ At $\mathrm{p}$ 332. For example, the failure of officers to suppress a riot: see $R v$ Kennett (1781) 172 ER 976.

${ }^{60}$ Articles 121 and 122 respectively. 


\section{COMBATING CORRUPTION}

condemnation and punishment", ${ }^{61}$ In fact, the cases have regularly combined the two offences, as the formulation in Att-Gen Ref 2003 indicates. ${ }^{62}$

This flexibility as to the scope of the offence inevitably impacts upon the formulation of the mental element. In Att-Gen Ref 2003 Pill LJ emphasised that "the concept of wilful misconduct is apt to the offence" and referred to the "helpful" words of Webster J in Graham $v$ Teesdale \& Another ${ }^{63}$ who stated that wilful misconduct means:

"...deliberately doing something which is wrong knowing it to be wrong or with reckless indifference as to whether it is wrong or not".

Pill LJ emphasised that there must be an awareness of the duty to act or a subjective recklessness as to the existence of the duty and added: ${ }^{64}$

"The recklessness test will apply to the question whether, in particular circumstances, a duty arises at all as well as to the conduct of the defendant if it does. The subjective test applies both to reckless indifference to the legality of the act or omission and in relation to the consequences of the act or omission".

To address the mens rea requirement as regards the neglect of official duties, Pill LJ stated "even in the context of misconduct said to arise from failure to perform a police duty, it was necessary for the Crown to establish some mental element". ${ }^{65}$ The result is that what constitutes the appropriate mens rea will vary depending upon the particular circumstances of a case. This was accepted by the Court of Appeal in $R v W$ where Lord Judge put it as follows:

"... as the nature of the conduct falling within the ambit of the offence

is very wide, any necessary element relating to the defendant's

\footnotetext{
${ }^{61}$ At page 394.

${ }^{62}$ This approach is also reflected in the views of Sir Anthony Mason NPJ in Shum Kwok Sher v HKSAR [2002] HKCFA 27, where he stated: "A public official culpably misconducts himself if he wilfully and intentionally neglects or fails to perform a duty to which he is subject by virtue of his office or employment without reasonable excuse or justification. A public official also culpably misconducts himself if, with an improper motive, he wilfully and intentionally exercises a power or discretion which he has by virtue of his office or employment without reasonable excuse or justification" at para 84. See also Article 19 of UNCAC, noted earlier.

${ }^{63}$ (1981) 81 LGR 117.

${ }^{64}$ Applying the House of Lords decision in $R v G$ [2003] UKHL 50.

${ }^{65}$ As Lord Judge put it in $R v W$ [2010] EWCA Crim 372 at para 5 after having referred to the views of Pill LJ.
} 
subjective state of mind cannot be identical for each and every one of its different manifestations". 66

This situation is hardly conducive to seeking certainty in the formulation of criminal offences and arguably any reform of the current position should consider the development of two separate offences.

\section{iii) To Such a Degree as to Amount to Abuse of the Public's Trust in the Office Holder}

For prosecutors and jurors alike, distinguishing between misconduct, mistakes or conflicts of interest by public officials that are merely disciplinary in nature and those which attract criminal liability is potentially problematic. ${ }^{67}$ The courts have emphasised that the test of culpability is that of "serious misconduct" and "must be of such a degree that the misconduct impugned is calculated to injure the public interest so as to call for condemnation and punishment". ${ }^{68}$ As Pill LJ put it "The threshold is a high one requiring conduct so far below acceptable standards as to amount to an abuse of the public's trust in the office holder. A mistake, even a serious one, will not suffice". ${ }^{69}$ Allegations of corruption or bribery are certainly covered but in other cases the relevant factors to be taken into account are (i) the responsibilities of the office and office holder, (ii) the importance of the public objects which they serve; and (iii) the nature and extent of the departure from those responsibilities. ${ }^{70}$

The issue as to the seriousness of the consequences of the breach in determining criminal liability remains uncertain. In Att-Gen Ref 2003, Pill LJ noted that:

"An act or omission which may have as its consequence a death, viewed in terms of the need for maintenance of public standards to be marked and the public interest to be asserted, is likely to be more

\footnotetext{
${ }^{66}$ Above, at para 8.

${ }^{67}$ The facts of $R v W$ provide a good example of the sometimes difficult line to be drawn between the two.

${ }^{68}$ Per Lord Widgery CJ in Dytham, above n 21, at 727-8. The Supreme Court of Canada has stated that the conduct of the public officer must represent a "marked departure" from the standards expected of an individual in the accused's position: see $R v$ Boulanger [2006] 2 SCR 49 at para 54.

${ }^{69}$ At para 56. This is further emphasised in the Crown Prosecution Guidance which states that "A charge of misconduct in public office should be reserved for cases of serious misconduct or deliberate failure to perform a duty which is likely to injure the public interest": see http://www.cps.gov.uk/legal/1_to_o/misconduct_in_public_office/ ${ }^{70}$ See the views Sir Anthony Mason NPJ in Shum Kwok Sher, above n 62, at para 86.
} 


\section{COMBATING CORRUPTION}

serious than one which would cause a trivial injury. This factor is likely to have less significance where, as in Shum Kwok Sher, the allegation is of corruption where the judgment upon the conduct may not vary directly in proportion to the amount of money involved". ${ }^{71}$

The potential difficulty with this approach is that it suggests that in some cases (such as those involving allegations of "corruption") misconduct in a public office is a conduct crime and that the consequences of the act or omission are merely a factor to take into account when considering its culpability or seriousness. In other situations, it seems that the consequences of the action/omission as well as the motive with which the public officer acted are the key factors in determining whether the public's trust was abused to such an extent as to attract criminal liability.

The point is well illustrated in the case of the unauthorised leaking of confidential information by a public servant. Arguably this, in itself, is a matter for the criminal law even where there was little or no resultant harm. As Judge LJ emphasised in Attorney-General Reference (No 140 of 2004): ${ }^{72}$

"The unauthorised disclosure of information held in any records kept and maintained only for public purposes should always be regarded as a serious offence. The amount of private information about each and every single citizen in this country, available to public servants, has increased, and with modern technology continuing increase is virtually inevitable. Citizens are entitled to assume that the information so kept will only be made available to those who are entitled to see it, and only for the express purposes permitted by law". 73

Yet the high-profile case of Green and Galley highlights the uncertainty surrounding this point. Here Galley, a civil servant, had allegedly leaked confidential government documents to Green, a (then) opposition member of Parliament. The action was contrary to the Civil Service Code (and therefore a disciplinary matter) but the issue was whether there were grounds to prosecute both men for the misconduct offence. In April 2009, the Director of Public Prosecutions (DPP) announced that he had concluded that there was no realistic prospect of a conviction against either of the men for the alleged

\footnotetext{
${ }^{71}$ At para 46.

72 [2004] EWCA Crim 3525.

${ }^{73}$ Para 9.
} 
offences and had decided that charges should not be brought. The reasons for this decision are noteworthy. ${ }^{74}$ In the first place, the DPP stated:

"I have concluded that there is evidence upon which a jury might conclude that the conduct of Mr Galley in passing various documents to $\mathrm{Mr}$ Green amounted to a clear breach of his public duties.... $\mathrm{Mr}$ Galley seriously breached the trust placed in him by the public.... I have also concluded that there is evidence upon which a jury might conclude that Mr Green aided or abetted Mr Galley's conduct and, in particular, his breach of the public's trust. There is, additionally, evidence upon which a jury might conclude that there was an ongoing relationship between Mr Galley and Mr Green, which Mr Green encouraged in the hope and expectation that Mr Galley would continue to supply restricted and/or confidential information to him" (my emphasis)."

\section{However, the DPP then asserted:}

"It is important that public officials should not leak restricted and/or confidential information. But, it is important that a breach of duty that might best be considered as a disciplinary matter should not be elevated to a criminal offence simply by virtue of the fact that the person leaking the information is a public official. Thus there is a need for an intense focus on any additional damage actually or potentially caused. In this case, I have concluded that there is little evidence of any additional damage caused by the leaks in question. The documents leaked undoubtedly touched on matters of legitimate public interest and Mr Green's purpose in using the documents was apparently to hold the government to account...".

This is a curious approach in that the DPP had already recognised that "Mr Galley seriously breached the trust placed in him by the public" by the unauthorised leaking of confidential information. Arguably, the fact that there was "little evidence of any additional damage caused by the leaks" was not a relevant consideration when determining whether the action itself constituted an abuse of the public's trust in the office holder and thus the threshold for a criminal prosecution had already been met by the action of Galley in passing confidential documents to Green. Whatever the motives for the decision of the DPP, it once again highlights the uncertainty as to the scope of the present law. This is reflected in the judgment of Pill LJ in Att Gen Ref 2003 who

\footnotetext{
74 "Decision on prosecution: Mr Christopher Galley and Mr Damien Green MP" CPS 16 April 2009: available at www.cps.gov.uk.
} 


\section{COMBATING CORRUPTION}

stated that "It will normally be necessary to consider the likely consequences of the breach in deciding whether the conduct falls so far below the standard of conduct to be expected of the officer as to constitute the offence" (my emphasis). He continued:

"There will be some conduct which possesses the criminal quality even if serious consequences are unlikely but it is always necessary to assess the conduct in the circumstances in which it occurs". ${ }^{75}$

Arguably, in cases of neglect of official duties the issue of consequences does not arise. An adjustment to the facts of Dytham illustrates the point. Suppose a police officer, whilst on duty and in uniform, witnesses an assault on a man. The officer takes no steps to intervene and, when the attack is over, merely drives away. However, unlike the situation in Dytham itself, the victim is only slightly injured in the attack. Assuming the requisite mens rea is present, it is the failure of the officer to respond appropriately that brings about liability for the misconduct offence and the consequences i.e. the extent of the injuries sustained by the victim, are irrelevant to the question of criminal liability. Again this illustrates the desirability of establishing two separate offences.

\section{iv) Without Justification or Excuse}

Pill LJ in Att-Gen Ref 2003 did not elaborate on this requirement but presumably this will be a matter for the court to take into consideration on a case by case basis.

\section{TOO "FLEXIBLE A FRIEND"?}

Recent developments regarding the misconduct office means that it a potentially useful "safety net" offence for prosecutors, especially as it remains an indictable only offence carrying a maximum sentence of life imprisonment. ${ }^{76}$ In 1996, Smith commented that "The most unsatisfactory feature of common law misdemeanours is the uncertainty about their elements

\footnotetext{
${ }^{75}$ At para 58.

${ }^{76}$ In $R v$ Rimmington, $R v$ Goldstein [2005] UKHL63 the House of Lords emphasised that: "good practice and respect for the primacy of statute require that conduct falling within the terms of a specific statutory provision should be prosecuted under that provision unless there is good reason for doing otherwise" (at para 3). Not infrequently, the misconduct offence is included as an alternative to a statutory offence.
} 
and limits and the boundaries between them". ${ }^{77}$ The series of cases since then certainly reinforce this view and highlight the "flexible" and somewhat uncertain nature and scope of an offence that covers serious cases involving corruption to cases which arguably are little more than serious disciplinary matters. The uncertainty surrounding its scope might yet attract the interest of the European Court of Human Rights.

The longevity of the offence is remarkable, especially in view of the numerous calls for the creation of a statutory offence. Yet its end may now be in sight for the Law Commission has announced that it will commence work in 2014 on a project that will involve the "simplification, clarification and codification of the common law offence" with a view to producing a final report in 2016. Hopefully this will address the problems and uncertainties explored in this part of the article.

\section{SECTION 2: THE TORT OF MISFEASANCE IN A PUBLIC OFFICE}

Like its criminal counterpart, the tort of misfeasance in a public office has a long history dating back at least to the case of Ashby $v$ White. ${ }^{78}$ The raison d'être of the tort is to address "bad faith in the exercise of public powers" 79 and thus to allow actions by a private individual or class of persons seeking recompense against public officers who have acted corruptly or otherwise seriously abused their powers: something which was not open to them through a public law suit. In other words, "misfeasance was created to offer the citizen in such a situation a head of liability under which to recover compensation" ${ }^{80}$ For example, where a voter was wilfully denied the right to vote by the returning officer; ${ }^{81}$ where a police officer forged the plaintiff's signature on a written statement withdrawing a complaint of theft, ${ }^{82}$ where a public official exercised his discretion to revoke a trader's licence for an improper purpose ${ }^{83}$ or where a public official awarded a government contract to a company knowing that he had no power to do so lawfully and that in doing so the plaintiff would be injured. ${ }^{84}$

\footnotetext{
${ }^{77}$ J Smith Case Comment "Misconduct in Public Office" [1996] Crim LR 57.

${ }^{78} 1$ Smith's LC (13th ed) 253; (1703) 92 ER 126.

${ }^{79}$ Lord Steyn in Three Rivers at page 193B.

${ }^{80}$ Marin \& Coye (below) para 11.

${ }^{81}$ Ashby $v$ White above $\mathrm{n} 78$.

${ }^{82}$ Kuddus v Chief Constable of Leicestershire [2001] UKHL 29.

${ }^{83}$ Roncarelli v Duplessis [1959] SCR 121 (Supreme Court of Canada).

${ }^{84}$ Harmon CFEM Facades (UK) Ltd $v$ The Corporate Officer of the House of Commons [1999] EWHC Technology 199.
} 


\section{COMBATING CORRUPTION}

As with its criminal counterpart, there was some uncertainty as to the scope of the tort. Indeed at one stage, the Court of Appeal effectively denied its existence. ${ }^{85}$ In 2003 the House of Lords in Three Rivers District Council v Bank of England (No 3), ${ }^{86}$ (Three Rivers), clarified and significantly expanded the scope of the tort. The decision of the Caribbean Court of Justice in the recent case of Marin and Coye $v$ Attorney General of Belize ${ }^{87}$ suggests that there is yet further scope to develop the tort.

The Three Rivers case itself concerned a claim that the Bank of England was liable to former depositors with the Bank of Credit and Commerce International (BCCI) for the tort of misfeasance in public office on the basis of the Bank of England's failure in its responsibilities in supervising banking activities in the United Kingdom. Whilst the claim was not upheld, Lord Steyn in the House of Lords took the opportunity to identify the ingredients of the tort as follows. ${ }^{88}$

1. The defendant must be a public officer;

2. The defendant, at material times, was exercising power as a public officer;

3. There are two different forms of liability: firstly, targeted malice by the defendant i.e. conduct specifically intended to injure a person(s) through the exercise of public power for an improper or ulterior motive; or secondly, where the defendant acted knowing that s/he had no power to do the act complained of and that the act would probably injure the plaintiff;

4. The plaintiff has sufficient interest or nexus to bring an action;

5. There is proof that the loss was caused by the abuse of power

6. The damage was not too remote.

Lord Steyn also recognised that "the tort bears some resemblance to the crime of misconduct in a public office". ${ }^{89}$ This means that much of the discussion in Section 1 of this article on the elements of criminal misconduct is also applicable to the tort. ${ }^{90}$ However Pill LJ noted that there must be some differences between the two, for example in that "the crime is committed upon an affront to the Crown, that is in this context the public interest, whereas the tort requires a balancing of interests as between public officers

${ }^{85}$ Davis v Bromley Corporation [1908] 1 KB 170.

${ }^{86}$ [2003] 2 AC 1.

${ }^{87}$ [2011] CCJ9 (AJ).

${ }^{88}$ [2003] 2 AC 1, pp 191-194.

${ }^{89}$ At page 191A, citing $R v$ Bowden above $\mathrm{n} 34$.

${ }^{90}$ For example, the principles laid down in $R v$ Bembridge are reflected in the civil case of Henly v Lyme Corporation 5 Bing 91. 
and individual members of the public or organisations seeking private remedies having asserted a loss which must be proved". 91

The particular significance of the Three Rivers decision was that it expanded the scope of the tort of misfeasance. As Chamberlain has argued, historically, the tort was limited to abuses of power that were directly targeted against a particular plaintiff, the essence being the misuse of power by a public officer with the deliberate intent to harm that person. ${ }^{92}$ However, she points out that under the test laid down in Three Rivers "it is only necessary to establish that the defendants were reckless as to whether their actions were lawful and reckless as to the fact that harm to the plaintiffs would likely ensue" and suggests that such an approach "cannot possibly keep the misfeasance tort within reasonable bounds". ${ }^{93}$ The decision of the Caribbean Court of Justice in Marin v Coye seeks to develop the tort still further.

\section{Further Developing the Tort? The Case of Marin \& Coye v Attorney General of Belize}

In Three Rivers, Lord Steyn stated that one of the essential elements of the tort is that "any plaintiff must have a sufficient interest to found a legal standing to sue. Subject to this qualification, principle does not require the introduction of proximity as a controlling mechanism in this corner of the law.... There is no reason why such an action cannot be brought by a particular class of persons, such as depositors at a bank, even if their precise identities were not known to the bank". ${ }^{94}$ This class will also include claims brought by corporate and other entities. ${ }^{95}$

It is in this context that the 2011 decision of the Caribbean Court of Justice (CCJ) in Marin and Coye v Attorney General of Belize (hereafter Marin \& Coye) is of particular interest. ${ }^{96}$ The facts were straightforward. The

\footnotetext{
91 Para 48. He added "[neither] the mental element associated with the misconduct, nor the threshold of misconduct should be set lower for the crime than for the tort" (at para 53). However, compare this view with the discussion in Marin and Coye below.

${ }^{92}$ See E Chamberlain "The Need for a 'Standing' Rule in Misfeasance in a Public Office” [2007] Oxford University Commonwealth Law Journal 215.

${ }^{93}$ At $\mathrm{p} 235$.

${ }^{94}$ At $\mathrm{p}$ 193. Lord Steyn also expressly agreed with the view of the trial judge that "If an officer deliberately does an act which he knows is unlawful and will cause economic loss to the plaintiff, I can see no reason in principle why the plaintiff should identify a legal right which is being infringed or a particular duty owed to him, beyond the right not to be damaged or injured by a deliberate abuse of power by a public officer".

95 See, for example, Bourgoin SA v Ministry of Agriculture, Fisheries and Food [1985] 3 WLR 1027.

96 [2011] CCJ 9 (AJ)
} 


\section{COMBATING CORRUPTION}

Attorney General of Belize filed a civil claim against two former government ministers alleging that during their tenure in office they had procured the sale of state land to a company beneficially owned and/or controlled by one of them at almost $\$ 1$ million below market value. ${ }^{97}$ Crucially, the claim was based on the common law tort of misfeasance in public office. The central question for the CCJ was whether the tort encompassed actions by the Attorney General, acting on behalf of the State, against its own officers, or former officers. By a majority of 3-2, the CCJ held that the Attorney General was competent to bring the action on behalf of the Crown against the appellants in order to recover compensation for the loss sustained. ${ }^{98}$

As noted below, all the judges of the CCJ recognised that some civil causes of action and remedies were already open to the State through which to combat corruption and misuse of public office. The essential disagreement focused on the view of the majority that the tort of misfeasance offered an extra tool for the State to fight corruption to be used not instead of but in addition to other available tools and that would serve to promote rather than erode integrity in public life. The two dissenting judges, de la Bastide PCCJ and Saunders JCCJ, took the view that "as a matter of policy" the court should not extend the tort to accommodate actions by the State and that "there can be little doubt that the appropriate course of action here is for the State to institute criminal proceedings". Further, they found it "impossible to conceive" a situation where corrupt acts occasioning serious material loss to the State would suffice to ground an action in tortious misfeasance but be insufficient to make out a prima facie criminal case. They concluded that:

"Extending the tort of misfeasance unnecessarily to give the AttorneyGeneral another choice of civil remedies does not strike a blow for the maintenance of probity by public officials. Quite the contrary, it has the opposite effect. It offers the miscreant the softer option of civil liability" (my emphasis). ${ }^{99}$

These views raise two key issues for consideration: (i) the use of the tort as an alternative to, or in addition, to the criminal offence of misconduct in public office; and (ii) whether, in any event, the tort accommodates actions brought on behalf of the State.

${ }^{97}$ The Government of Belize was claiming \$924,056.60, plus damages and interest, for the sale of 59 parcels of land in Coye's former constituency.

${ }^{98}$ It is not clear as to why the Director of Public Prosecutions did not bring a criminal prosecution for misconduct in public office, where the alleged facts certainly indicated that the former ministers had a case to answer.

${ }^{99}$ Para 44. 
(i) The Tort of Misfeasance as an Alternative, or in Addition, to the Criminal Offence of Misconduct in Public Office

As in the Marin \& Coye case itself, allegations of corrupt practices or abuse of power against public officials will always raise the prospect of a criminal prosecution for misconduct in public office (or some other offence) and this point was accepted by all members of the CCJ. However, that is not to overlook the sometimes sound policy reasons for considering the use of the tort of misfeasance as an alternative, or in addition, to criminal proceedings and there is nothing in law to prevent the two sets of proceedings from running side-by-side.

In the first place, the dissenting judges argued that in misfeasance cases, the courts were entitled to require a higher standard of probability than in a negligence claim. This is questionable. This view was based on the views of Denning LJ in Bater $v$ Bater" ${ }^{101}$ that "where criminal acts are being established in a civil case, courts are entitled to require a higher degree of probability than that which they would seek when considering whether negligence, for example, were established." This implies that there is little to differentiate between the standard of proof in criminal and "serious" civil cases, and as the dissenting judges acknowledged, this may explain why the "rate of success" for misfeasance suits was "notoriously low". ${ }^{102}$ Whilst they adopted a comparative analysis of many issues, strangely they made no reference to the 2008 House of Lords decision of In re Doherty ${ }^{103}$ where Lord Carswell adopted a forthright approach to the standard of proof:

23. Much judicial time has been spent in the last 50 or 60 years in attempts to explain what is required by way of proof of facts for a court or tribunal to reach the proper conclusion. It is indisputable that only two standards are recognised by the common law, proof on the balance of probabilities and proof beyond reasonable doubt. The latter standard is that required by the criminal law and in such areas of dispute as contempt of court or disciplinary proceedings brought against members of a profession. The former is the general standard applicable to all other civil proceedings and means simply, as Lord Nicholls of Birkenhead said in In re $H$ (Minors) (Sexual Abuse: Standard of Proof) [1996] AC 563, 586, that

${ }^{100}$ See, for example, Connelly $v$ DPP [1964] AC 1245 and $R v L$ [2006] 1 WLR 3092.

${ }^{101}$ [1950] 2 All ER 458 at 459.

102 Para 35.

103 [2008] 1 WLR 1499. 


\section{COMBATING CORRUPTION}

"a court is satisfied an event occurred if the court considers that, on the evidence, the occurrence of the event was more likely than not."

24. Any confusion which has crept into the application of this principle appears to have stemmed from statements made in a number of earlier cases, which may have been misunderstood but certainly have not always been applied correctly. The earliest situation appears to be Bater v Bater [1951] P 35, 37....

There is much to commend this approach and, if adopted elsewhere, then, contrary to the view of the dissenting judges, there is indeed a clear and significant distinction between the standard of proof in criminal and civil cases even where this involves an allegation of criminal conduct. ${ }^{104}$

Secondly, there remain significant challenges in successfully prosecuting corruption or misconduct cases, including working with the outdated and excessively technical rules of evidence that are still found in many Commonwealth countries. Other challenges, particularly associated with senior public officers and political figures, include the absconding of the official, constitutional immunity from prosecution, judicial corruption or the lack of the political will to prosecute. ${ }^{105}$

Thirdly, the view of the dissenting judges that the tort of misfeasance offers a "softer option" is also questionable. They certainly make the useful point that "the yardstick for measuring the appropriateness of suitable proceedings by the State against those who are involved in corrupt acts ought not, in our view, to be relegated merely to the degree to which the State's loss was recoverable through those proceedings". They also note that courts often impose massive fines on persons convicted of misfeasance in public office, ${ }^{106}$ albeit overlooking the fact that fines and criminal confiscation orders are dependent upon a criminal conviction. Yet as Maurice Kaye LJ emphasised in Hussain v Chief Constable of West Mercia:

"Misfeasance in public office is an intentional tort of considerable gravity. It is a tort of obloquy. As Lord Steyn explained in Three Rivers DC v Bank of England (No.3), it involves either targeted malice or bad faith on the part of a public official". ${ }^{107}$

${ }^{104}$ One of the majority judges, Anderson JCCJ, certainly recognised that the standard of proof differed significantly between tort and criminal proceedings: see para 147 .

${ }^{105}$ See generally Nicholls, especially chapter 8.

106 Para 39.

${ }^{107}$ [2008] EWCA Civ 1205 at para 20. 
It is also clear that exemplary damages may be claimed. ${ }^{108}$

It is against this background that the views of the majority in Marin \& Coye must be considered. In his judgment, Wit JCCJ focused on the need for governments to take firm action against public officials who had abused their office for personal enrichment with a view to the State recovering the stolen assets. He asserted that "if the objective is to recover economic loss due to the public officer's abuse of his power, the tort of misfeasance would be the appropriate remedy". ${ }^{109}$ This was echoed by Barnard JCCJ who noted that the option of a criminal prosecution was not within the remit of the Attorney General but that in any event "the Attorney General may be more concerned with recovering loss to the public purse which in this case is the economic value of the national lands amounting to $\$ 924,056.00 "{ }^{110}$ Wit JCCJ also emphasised that "the criminal law should not be used by the State with the main objective of getting compensation for damages suffered by the State even though it is clear that such a result could be obtained through the backdoor of high fines or, where the legislation allows it, through the side door of compensation orders". ${ }^{111}$

This approach reflects the fact that the use of civil actions and remedies is now a key strategy for States seeking to recover stolen state assets. As Sir Dennis Byron has observed "It is now realised that one of the key factors in reducing crime, is the delivery of civil justice where it was previously thought it was the use of criminal sanctions". ${ }^{112}$ There are already many examples of civil actions being brought by the State against corrupt public officials. ${ }^{113}$ Perhaps the classic example is the civil action brought by the AttorneyGeneral of Zambia in the High Court of England and Wales in which Peter Smith $\mathbf{J}$ found that the former President of Zambia, Frederick Chiluba, together with former Zambian ministers and public officials had conspired fraudulently to misappropriated millions of dollars belonging to the people of Zambia through a number of corrupt schemes. ${ }^{114}$ Interestingly, this led to a criminal prosecution of Chiluba taking place in Zambia, although in somewhat contentious circumstances, he was exonerated on all charges. ${ }^{115}$

\footnotetext{
${ }^{108}$ Kuddus v Chief Constable of Leicestershire [2001] UKHL 29.

109 Para 95.

110 Para 64.

${ }^{111}$ Para 96. Emphasis in the original.

112 Address at the Opening of the 2nd Biennial Conference of Judicial Officers of the Caribbean Court of Justice, 2011.

${ }^{113}$ For example the notorious case of A-G for Hong Kong v Reid [1994] 1 AC 324 (PC). See generally Nicholls chapters 8 and 9.

${ }^{114}$ See Attorney-General for Zambia v Meer Care and Desai [2007] EWHC 952 (Ch).

${ }^{115}$ For a discussion see Nicholls para 9.29 et seq.
} 


\section{COMBATING CORRUPTION}

Thus, it is erroneous to view serious misconduct by public officials, such as in Marin \& Coye, as inevitably requiring a criminal prosecution. Rather States have a choice between launching a criminal prosecution and a civil action (or utilising both) and this will depend upon the factors discussed above. It means that the key issue in Marin \& Coye was whether it was appropriate to extend the tort of misfeasance to actions by the State.

\section{(ii) Does the Tort of Misfeasance Extend to Actions by the State Against} Public Officials?

In their dissenting judgment, de la Bastide PCCJ and Saunders JCCJ emphasised that "the overwhelming consensus throughout the entire Commonwealth ... is that the tort protects the peculiar interests of a private entity or member of a class". ${ }^{116}$ Further that the "essentially private character of the tort" can be traced back to its roots which was to provide aggrieved individuals with the power to obtain recompense against public officials who had abused their powers: something which was not open to them through a public law suit. In other words, "Misfeasance was created to offer the citizen in such a situation a head of liability under which to recover compensation". ${ }^{117}$ They also noted that this reflected the position from the early case of Henly $v$ Lyme Corporation through to the House of Lords decision in Three Rivers as well as in jurisprudence from New Zealand, ${ }^{118}$ Australia ${ }^{119}$ and Canada. ${ }^{120}$

Curiously, and somewhat at odds with their views on the use of the criminal law in such cases, they also recognised that where the State has suffered loss in such circumstances, it already had effective alternative means to deal with the situation by bringing a civil suit against public officials for breach of fiduciary duty or breach of trust. As they emphasised: "The equitable causes of action are actually tailor-made for a case like this where Ministers of Government are alleged to have flouted their solemn responsibilities". ${ }^{121}$

The majority based their views on the need for courts to enjoy a wide array of options through which to combat corruption and misuse of public office and that different torts offered different remedies. Wit JCCJ rejected the argument that as there was no prior judicial authority for doing so, extending

\footnotetext{
${ }^{116}$ Para 10.

117 Para 11.

${ }^{118}$ Garrett v Attorney General [1997] 2 NZLR 332.

${ }^{119}$ Tampion $v$ Anderson [1973] VR 715.

${ }^{120}$ Odhavji Estate v Woodhouse [2003] 3 SC 263.

${ }^{121}$ Para 31.
} 
the tort to an action by the State was not maintainable ${ }^{122}$ and he pointed out that in all the cases cited by the dissenting judges the point had simply not been in issue. In any event, he asserted, somewhat unconvincingly perhaps, that extending the tort "is in no way creating a new principle but is simply the logical application of the principles which have already been developed by the common law...". ${ }^{123}$

Anderson JCCJ was of the view that the State possessed the entitlement to sue in order to protect its rights and that "in contemporary society, in proceedings by and against the Crown, the rights of parties are to be as nearly as possible the same as in a suit between individual persons". ${ }^{24} \mathrm{He}$ also pointed out that the availability of alternative causes of action "cannot be logically determinative" of the competence of the Attorney General to sue in misfeasance. Essentially the matter fell to the consideration of the remedy sought. Thus where the State desired to trace property purchased by a public official, an action for breach of fiduciary duty might be more useful. ${ }^{125}$ However the tort of misfeasance was appropriate where the Attorney General thought that an award of exemplary damages was appropriate and that the decision as to the type of civil proceedings to bring "to vindicate the State's corporate interests" should be left in the hands of the Attorney-General. ${ }^{126}$

\section{PART 3: SOME FINAL THOUGHTS}

The longevity of both the crime of misconduct and tort of misfeasance is remarkable and both are enjoying a new importance not only in England and Wales but also in a number of other jurisdictions. A key reason for this lies in the recognition that they both contribute to the development of a range of effective strategies through which states can seek to combat corrupt practices by their public officials

The use of the criminal law is a fundamental part of this approach and, as regards England and Wales, the coming into force of the Bribery Act 2010 is an important step forward. However, as noted earlier, the Act is of limited scope. Thus the criminal offence of misconduct in a public office will remain an important weapon in the prosecutorial armoury, albeit that the continued uncertainty about its elements and limits discussed in this article certainly

\footnotetext{
${ }^{122}$ At paras 89-90. He noted that in Southern Developers Ltd and Others $v$ AttorneyGeneral of Antigua and Barbuda (unreported 2007) that it was assumed but not decided that a State could bring the action see para 89.

${ }^{123}$ At para 93. Barnard JCCJ refers to the court introducing a "new dimension" to the tort: at para 66.

${ }^{124}$ At para 137.

${ }^{125}$ See, for example the Reid case above n 113.

126 At para 150.
} 


\section{COMBATING CORRUPTION}

merit attention. Here the proposed Law Commission project that will involve the "simplification, clarification and codification" of the common law offence will hopefully address these concerns.

Even with the statutory reform of the offence, for the reasons noted earlier, the criminal law has sometimes proved somewhat ineffective when seeking to combat corruption and serious misconduct by public officers. As a result, alternatives to criminal proceedings are becoming increasingly important prosecutorial tools, for example the use of formal plea negotiations. ${ }^{127}$ Yet the decision in Marin and Coye emphasises the increasing importance of utilising civil suits and remedies in the fight to enhance integrity in the public service and combat corrupt practices by public officials. Here the objective is to take away the profit from the abuse of office and enable the State and its people to recover its economic loss. Seen from this perspective, the decision of the Caribbean Court of Justice is noteworthy for, as Wit JCCJ stated, the decision offers an extra tool for the State to fight corruption to be used not instead of but in addition to other available tools and that will serve to promote rather than erode integrity in public life. As he put it, "At the end of the day the State has, as it should have, all the tools it needs to govern "for the common good of the people"128

In seeking to introduce a "new dimension" to the tort of misfeasance, the court in Marin \& Coye has suggested that it is "still developing" and that the Three Rivers decision is not the last word on the matter. ${ }^{129}$ It remains to be seen whether other States follow the lead of the Caribbean Court of Justice. What is clear is that courts worldwide are now exploring ways of extending and developing civil actions and remedies as a means to combat corruption in public office. As Anderson JCCJ put is so eloquently:

“... these developments may well portend the welcome emergence of a new matrix of causes of action hitherto frozen in time in their historical crypts and animated by judicial imprimatur". ${ }^{130}$

${ }^{127}$ See, in particular, the Attorney-General's Guidelines on Plea Discussions on Cases of Serious or Complex Fraud (2009).

128 At para 148 .

${ }^{129}$ See Wit JCCJ at para 75.

${ }^{130}$ At para 152. 